\title{
Antioxidative Responses and Candidate Gene Expression in Prairie Junegrass under Drought Stress
}

\author{
Yiwei Jiang ${ }^{1}$ \\ Department of Agronomy, Purdue University, West Lafayette, IN 47907 \\ Eric Watkins \\ Department of Horticultural Science, University of Minnesota, St. Paul, MN 55108 \\ Shuwei Liu, Xiaoqing Yu, and Na Luo \\ Department of Agronomy, Purdue University, West Lafayette, IN 47907
}

AdDitional INDEX words. Koeleria macrantha, water deficit, tolerance

\begin{abstract}
Prairie junegrass (Koeleria macrantha) is a native cool-season C3 grass that has shown potential as a lowinput turfgrass. An increased understanding of the physiological and molecular responses of prairie junegrass to water-deficit conditions is important for developing cultivars with enhanced drought tolerance. The objective of this study was to characterize the antioxidative responses and candidate gene expression in prairie junegrass subjected to drought stress. Two drought-tolerant (TOL-1 and TOL-2) and two drought-susceptible (SUS-1 and SUS-2) genotypes of prairie junegrass were subjected to 7 days of drought stress. Leaf relative water content (RWC) of SUS-1 and SUS-2 was $72.1 \%$ and $73.8 \%$ and RWC of TOL-1 and TOL-2 was $90.1 \%$ and $85.4 \%$ in drought-stressed plants, respectively. Drought stress did not affect chlorophyll fluorescence, lipid peroxidation, and antioxidative enzyme activities of superoxide dismutase (SOD), catalase (CAT), peroxidase, ascorbate peroxidase (APX), or glutathione reductase for tolerant or susceptible genotypes. The TOL-2 and SUS-2 genotypes were further examined for candidate gene expression. Drought stress did not alter expression levels of $C A T$ and chloroplastic copper/zinc $S O D(C u / Z n S O D)$, but increased levels of $A P X$ in either genotype, compared with their relative controls. Expression of P5CS encoding $\Delta^{1}$ pyrroline-5-carboxylate synthetase and P5CR encoding $\Delta^{\mathbf{1}}$-pyrroline-5-carboxylate reductase for proline biosynthesis were up-regulated under drought stress for both genotypes; however, expression of P5CR was more strongly induced under drought stress for TOL-2, compared with its control. The expression of 1-FFT encoding fructan:fructan 1-fructosyltransferase, which is involved in fructan biosynthesis, was strongly induced under drought stress for TOL2 but not detected under either control or drought stress conditions for SUS-2. These results indicate that the genes involved in proline and fructan biosynthesis may play an important role in drought tolerance in prairie junegrass.
\end{abstract}

Drought is one of the greatest environmental stresses in agriculture (Boyer, 1982). Perennial grasses are among the most economically important species used for livestock, fiber products, soil and water improvement and conservation, biofuel production, habitats for wildlife populations, recreation, and beautification (Beard, 2002; Health and Kaiser, 1985). Millions of hectares of turfgrass improve our quality of life, but the expanding uses of turfgrass can create challenges to grass management and production when the water supply is limited. Under severe drought conditions, water restrictions may be imposed on turfgrass areas. Water deficit is a major factor limiting grass quality and persistence, particularly for coolseason turfgrasses that require a relatively large amount of water for maintaining growth. Therefore, the development of drought-tolerant turfgrasses that require less water is becoming more important.

Prairie junegrass is native to the Great Plains and is widely distributed throughout much of the western U.S., as well as Europe and Asia. This cool-season grass has potential for use as a low-input turf in the northern U.S. due to its tolerance to droughty and alkaline soils, its ability to grow in sandy areas, and its survival at extreme temperatures (Dixon, 2000; Milnes

Received for publication 2 Apr. 2010. Accepted for publication 24 May 2010. ${ }^{1}$ Corresponding author. E-mail: yjiang@purdue.edu. et al., 1998). Prairie junegrass is a relatively slow-growing species, and this slow-growth characteristic could be advantageous for turf use due to the potential reduction in mowing costs (Watkins and Clark, 2009). Therefore, development of droughttolerant cultivars of prairie junegrass for use in northern climates would be a great benefit to turfgrass managers. A better understanding of physiological and molecular responses of prairie junegrass would be beneficial for germplasm improvement efforts with this species.

Antioxidant metabolism can play an important role in plant response to drought stress (Umezawa et al., 2006). Drought stress promotes accumulation of reactive oxygen species (ROS), potentially causing oxidative injury to proteins, lipids, and nucleic acids. Plants have evolved enzymatic and nonenzymatic antioxidant defense systems for scavenging and detoxifying ROS (Mittler, 2002). In enzymatic systems, superoxide dismutases (SOD) convert superoxide radicals to hydrogen peroxide $\left(\mathrm{H}_{2} \mathrm{O}_{2}\right)$ and molecular oxygen (Fridovich, 1995). Based on the metal cofactor used by enzymes, manganese SOD (MnSOD), iron SOD (FeSOD), and copper/zinc SOD $(\mathrm{Cu} /$ ZnSOD) have been identified at different cellular locations (Alscher et al., 2002). The $\mathrm{H}_{2} \mathrm{O}_{2}$ can be decomposed through cycles of ascorbate-glutathione, glutathione peroxidase, and catalase (CAT) (Mittler, 2002). The mechanisms of these antioxidative pathways suggest that maintenance of antioxidant 
enzyme activity may contribute to drought tolerance by removal of ROS toxicity. The responses of antioxidant enzymes to drought stress depend on stress intensity, duration, and plant species of perennial grass (Bian and Jiang, 2009; DaCosta and Huang, 2007).

Plants can adapt to drought stress by altering gene expression. Genes with diverse functions in drought tolerance have been identified in Arabidopsis thaliana (Seki et al., 2002) and other crop species (Guo et al., 2009; Rabello et al., 2008). Shinozaki and Yamaguchi-Shinozaki (2007) classified drought-induced genes into two groups based on their products: functional proteins and regulatory proteins. These genes can be abscisic acid (ABA)dependent or -independent (Valliyodan and Nguyen, 2006). Some of these genes have been transferred into crop species, and transgenic plants have shown increased drought tolerance (Bhatnagar-Mathur et al., 2009; Li et al., 2009; Umezawa et al., 2006). Identifying expression of candidate genes is essential for elucidating molecular adaptations of grass plants to drought stress. Furthermore, key candidate genes associated with drought tolerance can be used for improving drought tolerance of turfgrass through marker-assisted selection. The objective of this study was to characterize antioxidative responses and candidate gene expression of prairie junegrass subjected to drought stress.

\section{Materials and Methods}

INITIAL SCREENING. The plant material used in this study originated from germplasm collections made in 2005 (five sites in northeastern Colorado and northwestern Nebraska) and in 2006 (a single site in southeastern Minnesota). The collected seed was planted in July in the greenhouse at the University of Minnesota, and after $\approx 6$ weeks, the plants were transferred to a breeding nursery field at the University of Minnesota in St. Paul. The following spring, just before anthesis, plants that originated from the same collection area were transferred to individual crossing blocks (polycrosses) where the plants were allowed to intercross. A total of 11 polycrosses were established based on the original collection locations. Due to the small area of the original collection locations (typically less than 2 ha), it can be assumed that accessions from a single accession site have a high degree of genetic similarity. The seed was harvested individually from each plant in each polycross.

The collected seeds were planted in the greenhouse at the University of Minnesota, and the seedlings were maintained under greenhouse conditions (16-h photoperiod, $24^{\circ} \mathrm{C}$, fertilized weekly, watered as needed). Once the plants had been growing for $\approx 8$ weeks, individual genotypes were clonally propagated. A total of 143 genotypes that were successfully propagated were then used for initial drought tolerance screening. The selected genotypes represented all three collection regions (Colorado $=67$ genotypes; Nebraska $=52$ genotypes; Minnesota $=24$ genotypes). Drought screening was done in a growth chamber maintained at $24 / 15^{\circ} \mathrm{C}$ (day/night) temperatures with a $16-\mathrm{h}$ photoperiod $\left(350 \mu \mathrm{mol} \cdot \mathrm{m}^{-2} \cdot \mathrm{s}^{-1}\right)$. The trial consisted of three replications in time, which were each separated by $28 \mathrm{~d}$. Water was withheld from each replication starting on day 0 . Each replication was rated for drought tolerance (a 1-9 scale where $1=$ no green tissue, $9=$ no visible effects of drought stress) at 14, 21, and $28 \mathrm{~d}$. Using data from the 28-d rating, analysis of variance and means separation were done using PROC GLM of SAS (release 9.1 for Windows; SAS Institute, Cary, NC). We then identified two genotypes that were in the top statistical group for drought tolerance (TOL-1 and TOL-2) and two genotypes that were in the lowest statistical group for drought tolerance (SUS-1 and SUS-2).

GRowTH AND STRESS TREATMENT. These four genotypes were propagated to yield sufficient plant material for further testing. After several weeks of growth in the greenhouse, the similar number of plants of each genotype was transferred to pots (15 $\mathrm{cm}$ in diameter and $14.5 \mathrm{~cm}$ deep) containing the same amount of sandy-loam soil (coarse-loamy, mixed, superactive, Mesic Typic Endoaquolls) with a $\mathrm{pH}$ of 6.2 in a greenhouse at Purdue University. The plants were fertilized weekly with a complete soluble fertilizer (24N-3.5P-13.3K; Scotts, Marysville, OH) to provide $\approx 146 \mathrm{~kg} \cdot \mathrm{ha}^{-1} \mathrm{~N}$ per growing season. The plants were maintained in a greenhouse for $45 \mathrm{~d}$ and were then moved to a growth chamber for $7 \mathrm{~d}$ under temperatures of $20 \pm 0.1 / 15 \pm$ $0.1{ }^{\circ} \mathrm{C}$ (day/night), a relative humidity of $60 \%$, a $12-\mathrm{h}$ photoperiod, and a photosynthetically active radiation $(P A R)$ of $500 \mu \mathrm{mol} \cdot \mathrm{m}^{-2} \cdot \mathrm{s}^{-1}$ (fluorescent lamps) before drought stress. The plants were watered daily or were subjected to drought stress. After $7 \mathrm{~d}$ of treatment, drought-stressed leaf was slightly wilted or no wilting for TOL-1 and TOL-2 but was moderately to severely wilted for SUS-1 and SUS-2, respectively.

Water status and Whole-Plant measurements. Samples were collected at $7 \mathrm{~d}$ of drought stress. Soil samples were taken at 0 to $14 \mathrm{~cm}$ depth at $7 \mathrm{~d}$ of treatments, and soil moisture was measured by drying soils in an oven at $85{ }^{\circ} \mathrm{C}$ for $3 \mathrm{~d}$ and recording the weight loss. The relative water content (RWC) was determined according to the following equation: $\mathrm{RWC}=(\mathrm{FW}-$ $\mathrm{DW}) /(\mathrm{SW}-\mathrm{DW}) \times 100$, where $\mathrm{FW}$ is leaf fresh weight, $\mathrm{DW}$ is dry weight of leaves after drying at $85^{\circ} \mathrm{C}$ for $3 \mathrm{~d}$, and $\mathrm{SW}$ is the turgid weight of leaves after soaking in water for $4 \mathrm{~h}$ at room temperature $\left(\approx 20^{\circ} \mathrm{C}\right)$. Leaf photochemical efficiency was determined by measuring chlorophyll fluorescence (Fv/Fm) on five randomly selected leaves in each pot using a fluorescence meter (OS-30P; OPTI-Sciences, Hudson, NH). Leaf chlorophyll was extracted by soaking $150 \mathrm{mg}$ samples in $20 \mathrm{~mL}$ of dimethyl sulfoxide (DMSO) in the dark for $48 \mathrm{~h}$. The absorbance was read at 665 and $649 \mathrm{~nm}$ according to the method of Wellburn (1994). Additional leaves were taken and stored at $-80{ }^{\circ} \mathrm{C}$ for use in enzyme activity and gene expression studies.

AnTIOXIDANT ENZYMe ACTIVITY AND LIPID PEROXIDATION. The collected leaf tissue was ground into powder in liquid $\mathrm{N}$. Antioxidative enzymes were then extracted by mixing $0.1 \mathrm{~g}$ of leaf tissue power with $1.0 \mathrm{~mL}$ of extraction buffer $[50 \mathrm{~mm}$ potassium phosphate, $1 \mathrm{~mm}$ ethylenediaminetetraacetic acid (EDTA), and 1\% polyvinylpyrrolidone (PVP), $\mathrm{pH}$ 7.8]. The extractions were centrifuged at $15,000 g_{n}$ for $30 \mathrm{~min}$ at $4{ }^{\circ} \mathrm{C}$, and supernatant was collected for enzyme assay. The protein content was determined using Bradford's method (Bradford, 1976). The activity of SOD, ascorbate peroxidase (APX), glutathione reductase (GR), CAT, and peroxidase (POD) was assayed by using methods of Zhang and Kirkham (1996) with minor modifications (Wang and Jiang, 2007).

The SOD activity was measured by recording the rate of $p$-nitroblue tetrazolium chloride (NBT) reduction in absorbance at $560 \mathrm{~nm}$. The reaction mixture contained $50 \mathrm{~mm}$ phosphate buffer (pH 7.8), $13 \mathrm{~mm}$ methionine, $75 \mathrm{~mm}$ NBT, $2 \mathrm{~mm}$ riboflavin, $0.1 \mathrm{~mm}$ EDTA, and 20 to $30 \mu \mathrm{L}$ of enzyme extract and was illuminated under 80 to $90 \mu \mathrm{mol} \cdot \mathrm{m}^{-2} \cdot \mathrm{s}^{-1}$ for $10 \mathrm{~min}$. The reaction mixture lacking of enzyme developed maximum color as maximum reduction of NBT. The additional reaction mixture serving as the control was placed in the dark. One unit of SOD 
activity was defined as the amount of enzymes that caused $50 \%$ inhibition in the rate of NBT reduction. The activity of APX was assayed by recording the decrease in absorbance at $290 \mathrm{~nm}$ for $1 \mathrm{~min}$ and was calculated using an extinction coefficient of $2.8 \mathrm{~mm}^{-1} \cdot \mathrm{cm}^{-1}$. The $1.5-\mathrm{mL}$ reaction medium contained $50 \mathrm{~mm}$ potassium phosphate buffer ( $\mathrm{pH} 7.0), 0.5 \mathrm{~mm}$ ascorbic acid, $0.1 \mathrm{~mm}$ EDTA, $0.1 \mathrm{~mm} \mathrm{H}_{2} \mathrm{O}_{2}$, and $0.15 \mathrm{~mL}$ of enzyme extract. The reaction was started with the addition of $0.1 \mathrm{~mm} \mathrm{H}_{2} \mathrm{O}_{2}$. The activity of GR was assayed by measuring the decrease in absorbance at $340 \mathrm{~nm}$ for 1 min and was calculated using an extinction coefficient of $6.2 \mathrm{~mm}^{-1} \cdot \mathrm{cm}^{-1}$. The reaction mixture contained $0.1 \mathrm{M}$ phosphate buffer ( $\mathrm{pH} 7.8$ ), 1 mм EDTA, $1 \mathrm{~mm}$ oxidized glutathione (GSSG), $0.2 \mathrm{~mm}$ nicotinamide adenine dinucleotide phosphate (NADPH), and $0.15 \mathrm{~mL}$ of enzyme extract. The reaction was started by adding GSSG. The activity of CAT was determined by the decline in absorbance at $240 \mathrm{~nm}$ for $1 \mathrm{~min}$ and was calculated using an extinction coefficient of $39.4 \mathrm{M}^{-1} \cdot \mathrm{cm}^{-1}$. The assay contained $50 \mathrm{~mm}$ phosphate buffer $(\mathrm{pH}$ 7.0), $15 \mathrm{mM} \mathrm{H}_{2} \mathrm{O}_{2}$, and $0.1 \mathrm{~mL}$ of enzyme extract. The reaction was initiated by adding enzyme extract. The activity of POD was determined by an increase in absorbance at $470 \mathrm{~nm}$ for $1 \mathrm{~min}$ and was calculated using an extinction coefficient of $26.6 \mathrm{~mm}^{-1} \cdot \mathrm{cm}^{-1}$. The assay contained $20 \mathrm{~mm}$ guaiacol, $10 \mathrm{~mm}$ phosphate buffer $(\mathrm{pH} 7.0)$, and $0.1 \mathrm{~mL}$ of enzyme extract. The reaction was initiated by adding $\mathrm{H}_{2} \mathrm{O}_{2}$.

Lipid peroxidation was measured in terms of malondialdehyde (MDA) content, with some modifications. A $0.5-\mathrm{mL}$ aliquot of supernatant was mixed with $2 \mathrm{~mL}$ of $20 \%$ trichloroacetic acid containing $0.5 \%$ thiobarbituric acid. The mixture was heated at $95{ }^{\circ} \mathrm{C}$ for 30 min, quickly cooled, and was then centrifuged at $10,000 g_{\mathrm{n}}$ for $10 \mathrm{~min}$. The absorbance was read at 532 and $600 \mathrm{~nm}$ (Health and Packer, 1968). The concentration of MDA was calculated using an extinction coefficient of $155 \mathrm{~mm}^{-1} \cdot \mathrm{cm}^{-1}$.

GENE EXPRESSION [REVERSE TRANSCRIPTION-POLYMERASE CHAIN REACTION (RT-PCR)]. Plants responded to drought stress similarly between the two tolerant (TOL-1 and TOL-2) and between the two susceptible genotypes (SUS-1 and SUS-2). In addition, levels of soil moisture were similar for TOL-2 and SUS-2 after drought stress. Therefore, TOL-2 and SUS- 2 were selected to examine gene expression. The selection of candidate genes used for this study was based on: 1) gene encoding functional proteins or regulatory proteins; and 2) transformation of these genes has shown increased drought tolerance in different plant species.

Total RNA was isolated in leaf tissues using a TRI Reagent (Molecular Research Center, Cincinnati, $\mathrm{OH}$ ) and was treated with DNase (TURBO DNA-Free Kit; Ambion, Austin, TX) to remove contaminating genomic DNA. The first-strand cDNA was synthesized from $2 \mu \mathrm{g}$ of DNase-treated RNA using an iscript cDNA synthesis kit (Bio-Rad, Hercules, CA). The amplification profile was one cycle at $95^{\circ} \mathrm{C}$ for 4 min, followed by 26 to 30 cycles of $95^{\circ} \mathrm{C}$ for $30 \mathrm{~s}, 53^{\circ} \mathrm{C}$ for $30 \mathrm{~s}, 72^{\circ} \mathrm{C}$ for $40 \mathrm{~s}$, and a final extension step at $72{ }^{\circ} \mathrm{C}$ for $5 \mathrm{~min}$. The conserved regions of gene sequences were obtained from other plant species and were used to design primers for detecting gene expression in prairie junegrass (Table 1). The RT-PCR was repeated three times, the PCR products were resolved by $1.0 \%$ agarose gel, and the bands were determined with the gel image system (UVP, Upland, CA).

EXPERIMENTAL DESIGN AND DATA ANALYSIS. The experiment was a completely randomized design with four replicates (four
Table 1. The conserved region of primer sequences used for detecting gene expression in the leaves of prairie junegrass.

\begin{tabular}{|c|c|}
\hline Gene & Sequence \\
\hline \multirow[t]{2}{*}{ 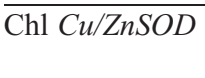 } & F: 5'-ATGGGTGCATATCDAYAG-3' \\
\hline & R: 5'-GCCAGTCTTCCACCAGCAT-3' \\
\hline \multirow[t]{2}{*}{$M n S O D$} & F: 5'-CAGRGBGCCATCAAGTTCAACG-3' \\
\hline & R: 5'-TACTGCAGGTAGTACGCATG-3' \\
\hline \multirow[t]{2}{*}{$C A T$} & F: 5'-CCTSTCATTGTGMGTTTCTC-3' \\
\hline & R: 5'-TTAACTCCRAAVCCATCCATATG-3' \\
\hline \multirow[t]{2}{*}{$P O D$} & F: 5'-AGGCCCAGTGCTHCAMCTTC-3' \\
\hline & R: 5'-TTGGTGTAGTAGGCGTTGTC-3' \\
\hline \multirow[t]{2}{*}{ Cyt $A P X$} & F: 5' -CTCMGAGGCTTCATCGCYGAGAAG-3' \\
\hline & R: 5'-AATCCAGAACGCTCCTTGTG-3' \\
\hline \multirow[t]{2}{*}{$G R$} & F: 5'-GCGATTTGCGAGMTCCCNTT-3' \\
\hline & R: 5'-ACAGCAATATATCCGCCACC-3' \\
\hline \multirow[t]{2}{*}{ NCED3 } & F: 5'-CSATYGGNGARYTNCAYGG-3' \\
\hline & R: 5'-YTTBGGRTGNGCDATCAT-3' \\
\hline \multirow[t]{2}{*}{$A A O 3$} & F: 5' - TGYGGYGAAGGDGGNTGYGG-3' \\
\hline & R: 5'-CATBCCNGGNGTRCARAAVCC-3' \\
\hline \multirow[t]{2}{*}{ P5CS } & F: 5'-GAGGDGGHATGACWGCNAAAG-3' \\
\hline & R: 5'-CATCHGCATGNCCNAGVAC-3' \\
\hline \multirow[t]{2}{*}{$P 5 C R$} & F: 5'-ARGCWGCWTCAGTNATG-3' \\
\hline & R: 5'-CAGCNACTCCNCCATC-3' \\
\hline \multirow[t]{2}{*}{$1-F F T$} & F: 5'-TCAGGACGGCGAGGT-3' \\
\hline & R: 5'-TGCGCCACGTGTTGTC-3' \\
\hline \multirow[t]{2}{*}{ SUSY } & F: 5'-AGCCTCTACCCACTGCTCAA-3' \\
\hline & R: 5'-GAGCTGGGAGTGTCTTCAGG-3' \\
\hline \multirow[t]{2}{*}{$P I P 1 ; 4$} & F: 5'-GCNGGNATHGCNGAGTT-3' \\
\hline & R: 5' -CNGARAADACNGTGTARACNAG-3' \\
\hline \multirow[t]{2}{*}{$B A D H$} & F: 5' -CGHGCNATYGCNGCYAAG-3' \\
\hline & R: 5'-CTRCADATYTGDCCRTTKGTCC-3' \\
\hline \multirow[t]{2}{*}{$A C C$} & F: 5'-GGDTCDTTTGGYCCWAGRGARG-3' \\
\hline & R: 5'-DGCDCCWATKCCHACHGT-3' \\
\hline \multirow[t]{2}{*}{$W A X 2$} & F: 5' -GCWGCNCTSAACAAGAAYGARGC-3' \\
\hline & R: 5'-GGCACSACRAACTGRTGGAARTG-3' \\
\hline \multirow[t]{2}{*}{$M Y B$} & F: 5'-GGYGADGSNCGYTGGAAC-3' \\
\hline & R: 5'-GSTGYTTRGCBTGYTTYTGSAC-3' \\
\hline
\end{tabular}

pots) for each genotype. The well-watered and drought-stressed pots were arranged randomly within the growth chamber. Treatment effects were determined by the analysis of variance. Significance of parameters between treatments and genotypes were analyzed using PROC GLM of SAS. Treatment and genotype means were separated using the least significant difference (LSD) test at $P<0.05$.

\section{Results and Discussion}

SOIL MOISTURE AND WHOLE-PLANT RESPONSES. Drought stress significantly decreased soil moisture content (SMC) for all grasses (Table 2). At the end of $7 \mathrm{~d}$, SMC was $3.7 \%$ and $5.3 \%$ for SUS- 1 and SUS- 2 and $6.2 \%$ and $5.9 \%$ for TOL- 1 and TOL2 , respectively. Under these soil moisture conditions, RWC was $72.1 \%$ and $73.8 \%$ for SUS- 1 and SUS-2, and RWC was $90.1 \%$ and $85.4 \%$ for TOL- 1 and TOL-2, respectively. TOL-1, TOL-2, and SUS-2 showed similar SMC at $7 \mathrm{~d}$, but TOL-1 and TOL-2 had higher RWC than SUS-1 and SUS-2 (Table 2). Milnes et al. (1998) found that Koeleria macrantha plants from the United Kingdom, when grown under drought stress, could maintain tiller base RWC similar to a well-watered control until soil moisture content fell to $9 \%$. The low soil moisture content that 
Table 2. Effects of $7 \mathrm{~d}$ of drought stress on soil moisture content (SMC), leaf relative water content (RWC), chlorophyll concentration (Chl), and chlorophyll fluorescence (Fv/Fm) of prairie junegrass genotypes. C and D represent the well-watered control and drought stress, respectively.

\begin{tabular}{|c|c|c|c|c|c|c|c|c|}
\hline \multirow[b]{3}{*}{ Accession } & \multicolumn{2}{|c|}{ SMC } & \multicolumn{2}{|c|}{ RWC } & \multicolumn{2}{|c|}{ Chl } & \multicolumn{2}{|c|}{$\mathrm{Fv} / \mathrm{Fm}$} \\
\hline & $\mathrm{C}$ & $\mathrm{D}$ & $\mathrm{C}$ & $\mathrm{D}$ & $\mathrm{C}$ & $\mathrm{D}$ & $\mathrm{C}$ & $\mathrm{D}$ \\
\hline & \multicolumn{2}{|c|}{$\left(\%^{z}\right)$} & \multicolumn{2}{|c|}{$(\%)$} & \multicolumn{2}{|c|}{$\left(\mu g \cdot \mathrm{mg}^{-1}\right.$ dry wt) } & & \\
\hline SUS-1 & $19.6 \mathrm{abA}^{\mathrm{y}}$ & $3.7 \mathrm{bB}$ & $98.0 \mathrm{aA}$ & $72.1 \mathrm{bB}$ & $7.81 \mathrm{aA}$ & $8.73 \mathrm{aA}$ & $0.82 \mathrm{aA}$ & $0.81 \mathrm{aA}$ \\
\hline SUS-2 & $18.2 \mathrm{bA}$ & $5.3 \mathrm{aB}$ & $97.8 \mathrm{aA}$ & $73.8 \mathrm{bB}$ & $7.35 \mathrm{abA}$ & $8.05 \mathrm{aA}$ & $0.81 \mathrm{aA}$ & $0.77 \mathrm{aA}$ \\
\hline TOL-2 & $18.7 \mathrm{abA}$ & $5.9 \mathrm{aB}$ & $97.4 \mathrm{aA}$ & $85.4 \mathrm{aA}$ & $6.66 \mathrm{bA}$ & $7.77 \mathrm{aA}$ & $0.81 \mathrm{aA}$ & $0.80 \mathrm{aA}$ \\
\hline
\end{tabular}

${ }^{\mathrm{z}}$ Gravimetric basis.

${ }^{\mathrm{y}}$ Means followed by the same lower case letter within a column for a given measurement were not significantly different at $P<0.05$; means followed by the same capital case letter within a row for a given genotype were not significantly different at $P<0.05$.

causes plant wilting is highly dependent upon the soil type (Kirkham, 2005). When prairie junegrass was growing in sandy-loam soil, leaf wilting occurred before $7 \mathrm{~d}$ of drought stress for SUS-1 and SUS-2 (visual observation) but became more severe when SMC dropped to below $6 \%$ after $7 \mathrm{~d}$; however, drought-stressed leaves of TOL-1 and TOL-2 were only slightly wilted or not wilting under the similar soil moisture levels. It is known that changes in leaf water content reflect the responses of the whole plant to drought stresses (Matin et al., 1989). These results indicate that maintenance of leaf water content contributes to the superior drought tolerance of TOL-1 and TOL-2.

Chlorophyll content (Chl) did not change under drought stress for all genotypes except for TOL-1, which showed a Chl increase of $13 \%$ (Table 2). Drought stress did not affect the Fv/ Fm of any genotypes, suggesting that leaf chemical efficiency is not particularly sensitive to moderate to severe water deficit conditions in prairie junegrass genotypes, regardless of their sensitivities. Similar results were also found in other plant species under drought stress (Bian and Jiang, 2009; Ohashi et al., 2006; Zulini et al., 2007). It has been known for a long time that photosynthesis is less sensitive to drought stress than stomatal closure (Troughton, 1969). The drought stress has to be prolonged and rather severe before the chloroplasts start to break down. The mesophyll resistance associated with photosynthesis (not transpiration) did not vary with the relative leaf water content down to $75 \%$ but increased progressively as RWC dropped from $75 \%$ to $56 \%$ (Troughton, 1969). Even when photosynthesis and stomatal conductance were strongly inhibited by drought stress, leaf chemical efficiency was still unchanged in plants (Ohashi et al., 2006).

ANTIOXIDATIVE ENZYMe ACTIVITY AND GENE EXPRESSION. Significant differences in activities of SOD, APX, GR, CAT,
POD, and MDA content were observed among all prairie junegrass genotypes for both treatments except for SOD under drought stress (Table 3 ). However, there were no differences in enzyme activities and MDA content between the control and drought stress treatment for all genotypes. The unchanged MDA content and stable enzyme activities indicate that light to moderate drought stress ( $\mathrm{RWC} \approx 80 \%-70 \%$ ) might not cause oxidative injury to prairie junegrass, although SUS-1 and SUS2 became wilted when RWC dropped to below $80 \%$. Similar results in activities of SOD, CAT, POD, GR, and MDA content were found in kentucky bluegrass (Poa pratensis) when RWC dropped to 68\% (Bian and Jiang, 2009). Increased, decreased, and unchanged antioxidant enzyme activities have been found in different perennial grasses in response to drought stress $(\mathrm{Fu}$ and Huang, 2001; Zhang and Schmidt, 1999), depending on stress conditions and plant species. Under severe dehydration (RWC $<40 \%$ ), however, a general decline in antioxidant enzyme activities and an increase in lipid peroxidation were observed in Agrostis canina L., Agrostis stolonifera L., and Agrostis capillaris L. (DaCosta and Huang, 2007).

Drought stress did not alter expression levels of CAT and chloroplastic $\mathrm{Cu} / \mathrm{ZnSOD}$ in TOL-2 or SUS-2 (Fig. 1). The expressions of $M n S O D$ and $G R$ were slightly increased and $A P X$ was upregulated under drought stress in both genotypes. The higher level of $P O D$ expression was only found in SUS-2 under drought stress. Similar expression patterns of CAT and $A P X$ were found in kentucky bluegrass (Bian and Jiang, 2009) and pea (Pisum sativum) leaves (Mittler and Zilinskas, 1994), respectively, exposed to a similar intensity of drought stress. Torres-Franklin et al. (2008) found that expression of $G R$ was strongly upregulated in cowpea (Vigna sinensis) leaves under drought stress in a susceptible cultivar but remained stable in a tolerant cultivar. It has been shown that the transformation of

Table 3. Effects of $7 \mathrm{~d}$ of drought stress on activities of superoxide dismutase (SOD), ascorbate peroxidase (APX), glutathione reductase (GR), catalase (CAT), peroxidase (POD), and malondialdehyde (MDA) content of prairie junegrass genotypes. C and D represent well-watered control and drought stress, respectively.

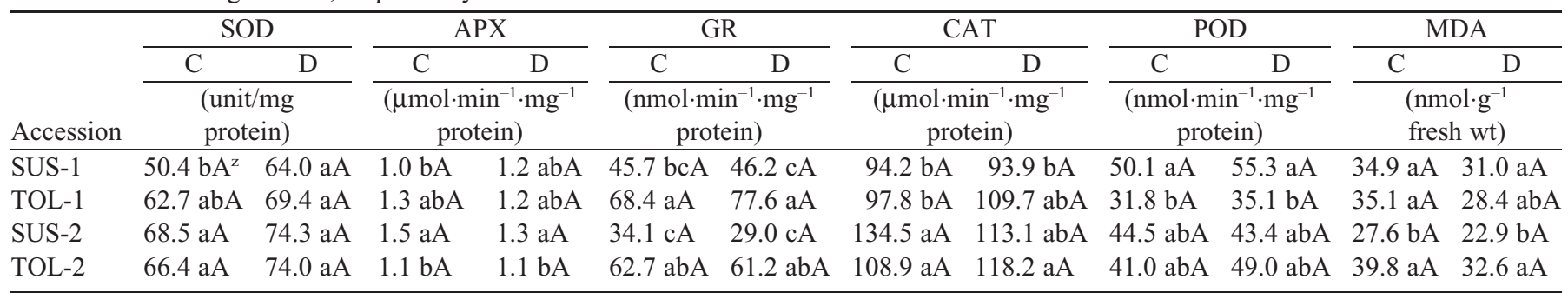

${ }^{\mathrm{z}}$ Means followed by the same lower case letter within a column for a given measurement were not significantly different at $P<0.05$; means followed by the same capital case letter within a row for a given genotype were not significantly different at $P<0.05$. 


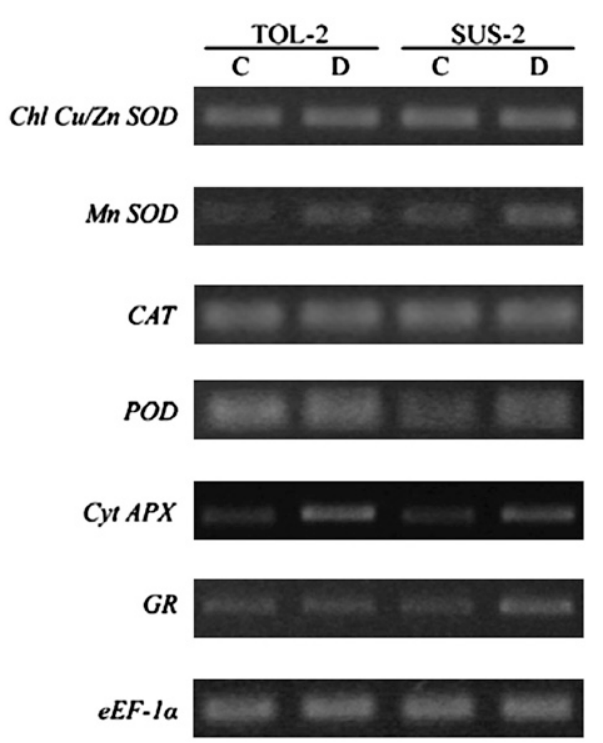

Fig. 1. Gene expressions of chloroplastic copper/zinc superoxide dismutase (Chl $\mathrm{Cu} / \mathrm{ZnSOD})$, manganese superoxide dismutase $(\mathrm{MnSOD})$, catalase $(C A T)$, peroxidase $(P O D)$, cytosolic ascorbate peroxidase (Cyt $A P X)$, and glutathione reductase $(G R)$ in the leaves of prairie junegrass genotypes under $7 \mathrm{~d}$ of drought stress, respectively. $\mathbf{C}$ and $\mathbf{D}$ represent the well-watered control and drought stress, respectively. $e E F-1 \alpha$ was internal loading control.

$C u / Z n S O D, A P X$, and $M n S O D$ increased dehydration and drought tolerance in potato (Solanum tuberosum) (Kwak et al., 2009) and tobacco (Nicotiana tabacum) (Li et al., 2009). Taken together with our results, this indicates that the stable or increased expression of these antioxidant genes may confer drought tolerance on plants, including prairie junegrass.

EXPRESSION OF OTHER CANDIDATE GENES. Drought-induced candidate genes have been identified in several different plant species, and transformation of some of these genes to crop plants has increased drought tolerance (Bhatnagar-Mathur et al., 2009; Khan et al., 2009; Mahdieh et al., 2008). In this study, 11 of these candidate genes with diverse functions were selected to study expression patterns in prairie junegrass under drought stress (Fig. 2). 9-cis-epoxycarotenoid dioxygenase (NCED) and aldehyde oxidase 3 (AAO3) are key enzymes in the biosynthesis of ABA (Seo et al., 2000; Seo and Koshiba, 2002). Expression of NCED was not detected in the control plants but was found in the drought-stressed plants of TOL-2. Overexpression of NCED3 in A. thaliana has improved drought tolerance by increasing the endogenous ABA level and enhancing the transcription of ABA-inducible or ABA-responsive genes (Iuchi et al., 2001). The upregulation of NCED but not $A A O 3$ in TOL-2 might facilitate plant tolerance to drought stress. Similar trends were also found in expressions of $B A D H$ and $A C C . B A D H$ is involved in synthesis of glycine betaine (GB), an important compatible solute that accumulates and protects plants against abiotic stresses (Khan et al., 2009). The gene encoding acetyl-CoA carboxylase (ACC), a key enzyme of lipid biosynthesis, increased in relative abundance along with a corresponding increase in epicuticular wax content in the tolerant genotype of peanut (Arachis hypogaea) (Kottapalli et al., 2009), suggesting its role in drought stress tolerance. Other drought-inducible genes encoding functional proteins include aquaporin (e.g., PIP1;4), which facilitates water transport (Mahdieh et al., 2008), wax/cuticle biosynthesis (e.g.,

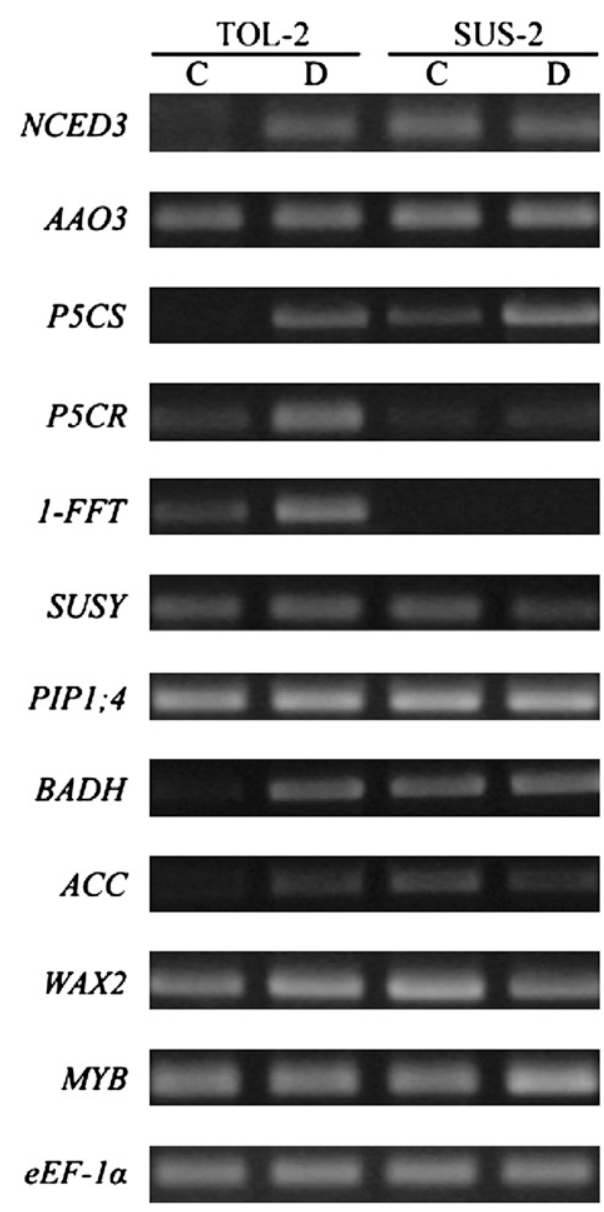

Fig. 2. Gene expressions of 9-cis-epoxycarotenoid dioxygenase (NCED), aldehyde oxidase 3 (AAO3), $\Delta^{1}$-pyrroline-5-carboxylate synthetase (P5CS), $\Delta^{1}$-pyrroline-5-carboxylate reductase (P5CR), fructan:fructan 1-fructosyltransferase $(1-F F T)$, sucrose synthase $(S U S Y)$, aquaporin $(P I P 1 ; 4)$, betaine aldehyde dehydrogenase $(B A D H)$, cuticular wax $(W A X 2)$, and acetyl-CoA carboxylase $(A C C)$, a transcription factor $(M Y B)$ in the leaves of prairie junegrass genotypes under $7 \mathrm{~d}$ of drought stress, respectively. $\mathbf{C}$ and $\mathbf{D}$ represent the well-watered control and drought stress, respectively. $e E F-1 \alpha$ was internal loading control.

$W A X 2$ ) (Chen et al., 2003), and $M Y B$, an ABA-dependent transcription factor and an activator of the expression of other genes (Cominelli et al., 2005; Mattana et al., 2005). But there were no differences in expression of PIP1;4, WAX2, and $M Y B$ for either genotype of prairie junegrass under both treatments.

Proline is highly accumulated in the stress-tolerant species under drought stress (Türkan et al., 2005). Both P5CS and P5CR are important enzymes in the proline biosynthesis pathway (Delauney and Verma, 1993). Gene expression of P5CS and P5CR were upregulated under drought stress for both genotypes; $P 5 C R$, in particular, was strongly induced under drought stress in TOL-2. The results indicate that upregulation of P5CR may increase drought tolerance of prairie junegrass. Transgenic plants of soybean (Glycine max) (De Ronde et al., 2004), petunia (Petunia hybrida) (Yamada et al., 2005), and chickpea (Cicer arietinum) (Bhatnagar-Mathur et al., 2009) carrying P5CS or P5CR exhibit higher leaf RWC and proline concentration and are more drought tolerant than the control plants. 
Expression of 1-FFT encoding fructan:fructan 1-fructosyltransferase was strongly induced under drought stress for TOL2 but was not shown for SUS-2 under control or drought stress conditions. 1-FFT is one of the key enzymes in fructan biosynthesis (Kawakami and Yoshida, 2005). Fructan has been recognized as a protective agent against abiotic stresses, including cold and drought (Valluru and Van den Ende, 2008). The expression of $1-F F T$ in TOL-2 but not in SUS-2 suggests its role in promoting drought tolerance. Under drought stress, the expression of SUSY, which encodes sucrose synthase, did not change in TOL-2, but slightly decreased in SUS-2. Sucrose synthase is a key enzyme in plant sucrose catabolism, mobilizing sucrose into multiple pathways involved in metabolic, structural, and storage functions (Subbaiah et al., 2007). Expression of SUSY was upregulated in drought-tolerant cultivars of maize (Zea mays) exposed to drought stress (Hayano-Kanashiro et al., 2009). Our results indicate that SUSY has a positive impact on drought tolerance of prairie junegrass.

In summary, prairie junegrass genotypes exhibited varied leaf water status in response to drought stress. Moderate drought stress did not change antioxidant enzyme activities or lipid peroxidation in this species. Genes involved in proline $(P 5 C R)$ and fructan (1-FFT) biosynthesis could play important roles in drought tolerance in prairie junegrass. Further research is needed to identify important candidate genes and markers linked to drought tolerance that can be applied to the genetic improvement of prairie junegrass for enhanced drought tolerance.

\section{Literature Cited}

Alscher, R.G., N. Erturk, and L.S. Heath. 2002. Role of superoxide dismutases (SODs) in controlling oxidative stress in plants. J. Expt. Bot. 53:1331-1341.

Beard, J.B. 2002. Turf management for golf courses. 2nd ed. Ann Arbor Press, Chelsea, MI.

Bhatnagar-Mathur, P., V. Vadez, M.J. Devi, M. Lavanya, G. Vani, and K.K. Sharma. 2009. Genetic engineering of chickpea (Cicer arietinum L.) with the P5CSF129A gene for osmoregulation with implications on drought tolerance. Mol. Breed. 23:591-606.

Bian, S. and Y. Jiang. 2009. Reactive oxygen species, antioxidant enzyme activities and gene expression patterns in leaves and roots of kentucky bluegrass in response to drought stress and recovery. Sci. Hort. 120:264-270.

Boyer, J.S. 1982. Plant productivity and environment. Science 218: 7443-7448.

Bradford, M.M. 1976. A rapid and sensitive method for the quantitation of microgram quantities of protein utilizing the principle of protein-dye binding. Anal. Biochem. 72:248-254.

Chen, X., S.M. Goodwin, V.L. Boroff, X. Liu, and M.A. Jenks. 2003. Cloning and characterization of the WAX2 gene of Arabidopsis involved in cuticle membrane and wax production. Plant Cell 15:1170-1185.

Cominelli, E., M. Galbiati, A. Vavasseur, L. Conti, T. Sala, M. Vuylsteke, N. Leonhardt, S. Dellaporta, and C. Tonelli. 2005. A guard-cell-specific MYB transcription factor regulates stomatal movements and plant drought tolerance. Curr. Biol. 15:11961200.

DaCosta, M. and B. Huang. 2007. Changes in antioxidant enzyme activities and lipid peroxidation for bentgrass species in responses to drought stress. J. Amer. Soc. Hort. Sci. 132:319-326.

Delauney, A.J. and D.P.S. Verma. 1993. Proline biosynthesis and osmoregulation in plants. Plant J. 4:215-223.

De Ronde, J.A., W.A. Cressc, G.H.J. Krügerd, R.J. Strasserd, and J.V. Stadenb. 2004. Photosynthetic response of transgenic soybean plants, containing an Arabidopsis P5CR gene, during heat and drought stress. J. Plant Physiol. 161:1211-1224.

Dixon, J.M. 2000. Koeleria macrantha (Ledeb.) Schultes (K. alpigena Domin, K. cristata (L.) Pers. pro parte, K. gracilis Pers., K. albescens auct. non DC.). J. Ecol. 88:709-726.

Fridovich, I. 1995. Superoxide radical and superoxide dismutases. Annu. Rev. Biochem. 64:97-112.

$\mathrm{Fu}$, J. and B. Huang. 2001. Involvement of antioxidants and lipid peroxidant in the adaptation of two cool-season grasses to localized drought stress. Environ. Exp. Bot. 45:105-114.

Guo, P.G., M. Baum, S. Grando, S. Ceccarelli, G.H. Bai, R.H. Li, M.V. Korff, R.K. Varshney, A. Graner, and J. Valkoun. 2009. Differentially expressed genes between drought-tolerant and drought-sensitive barley genotypes in response to drought stress during the reproductive stage. J. Expt. Bot. 60:3531-3544.

Hayano-Kanashiro, C., C. Calderón-Vázquez, E. Ibarra-Laclette, L. Herrera-Estrella, and J. Simpson. 2009. Analysis of gene expression and physiological responses in three Mexican maize landraces under drought stress and recovery irrigation. PLoS ONE 4:e7531.

Health, M.E. and C.J. Kaiser. 1985. Forages in a changing world, p. 3-11. In: M.E. Health, R.F. Barners, and D.S. Metcalfe (eds.). Forages: The science of grassland agriculture. 4th ed. Iowa State University Press, Ames, IA.

Health, R.L. and L. Packer. 1968. Photoperoxidation in isolated chloroplasts. I. Kinetics and stoichiometry of fatty acid peroxidation. Arch. Biochem. Biophys. 125:189-198.

Iuchi, S., M. Kobayashi, T. Taji, M. Naramoto, M. Seki, T. Kato, S. Tabata, Y. Kakubari, K. Yamaguchi-Shinozaki, and K. Shinozaki. 2001. Regulation of drought tolerance by gene manipulation of 9-cisepoxycarotenoid dioxygenase, a key enzyme in abscisic acid biosynthesis in Arabidopsis. Plant J. 27:325-333.

Kawakami, A. and M. Yoshida. 2005. Fructan:fructan 1-fructosyltransferase, a key enzyme for biosynthesis of graminan oligomers in hardened wheat. Planta 223:90-104.

Khan, M.S., X. Yu, A. Kikuchi, M. Asahina, and K.N. Watanabe. 2009. Genetic engineering of glycine betaine biosynthesis to enhance abiotic stress tolerance in plants. Plant Biotechnol. 26: 125-134.

Kirkham, M.B. 2005. Soil and plant water relations. Elsevier, Amsterdam, The Netherlands.

Kottapalli, K.R., R. Rakwal, J. Shibato, G. Burow, D. Tissue, J. Burke, N. Puppala, M. Burow, and P. Payton. 2009. Physiology and proteomics of the water-deficit stress response in three contrasting peanut genotypes. Plant Cell Environ. 32:380-407.

Kwak, S.-S., S. Lim, L. Tang, S.-Y. Kwon, and H.-S. Lee. 2009. Enhanced tolerance of transgenic crops expressing both superoxide dismutase and ascorbate peroxidase in chloroplasts to multiple environmental stress, p. 197-203. In: M. Ashral, M. Ozturk, and H.R. Athar (eds.). Salinity and water stress. Springer, Dordrecht, The Netherlands.

Li, Y.-J., R.-L. Hai, X.-H. Du, X.-N. Jiang, and H. Lu. 2009. Overexpression of a Populus peroxisomal ascorbate peroxidase (PpAPX) gene in tobacco plants enhances stress tolerance. Plant Breed. 128:404-410.

Mahdieh, M., A. Mostajeran, T. Horie, and M. Katsuhara. 2008. Drought stress alters water relations and expression of PIP-type aquaporin genes in Nicotiana tabacum plants. Plant Cell Physiol. 49:801-813.

Matin, M.A., J.H. Brown, and H. Ferguson. 1989. Leaf water potential, relative water content, and diffusive resistance as screening techniques for drought resistance in barley. Agron. J. 81:100-105.

Mattana, M., E. Biazzi, R. Consonni, F. Locatelli, C. Vannini, S. Provera, and I. Coraggio. 2005. Overexpression of Osmyb4 enhances compatible solute accumulation and increases tolerance of Arabidopsis thaliana. Physiol. Plant. 125:212-223.

Milnes, K.J., W.J. Davies, J.S. Rodwell, and B.J. Francis. 1998. The responses of Briza media and Koeleria macrantha to drought and rewatering. Funct. Ecol. 12:665-672. 
Mittler, R. 2002. Oxidative stress, antioxidants and stress tolerance. Trends Plant Sci. 7:405-410.

Mittler, R. and B.A. Zilinskas. 1994. Regulation of pea cytosolic ascorbate peroxidase and other antioxidant enzymes during the progression of drought stress and following recovery from drought. Plant J. 5:397-405.

Ohashi, Y., N. Nakayama, H. Saneoka, and K. Fujita. 2006. Effects of drought stress on photosynthetic gas exchange, chlorophyll fluorescence and stem diameter of soybean plants. Biol. Plant. 50:138-141.

Rabello, A.R., C.M. Guimarães, P.H.N. Rangel, F.R. Silva, D. Seixas, E. Souza, A.C.M. Brasileiro, C.R. Spehar, M.E. Ferreira, and A. Mehta. 2008. Identification of drought-responsive genes in roots of upland rice (Oryza sativa L). BMC Genomics 9:485.

Seki, M., M. Narusaka, J. Ishida, T. Nanjo, M. Fujita, Y. Oono, A. Kamiya, M. Nakajima, A. Enju, T. Sakurai, M. Satou, K. Akiyama, T. Taji, K. Yamaguchi-Shinozaki, P. Carninci, J. Kawai, Y. Hayashizaki, and K. Shinozaki. 2002. Monitoring the expression profiles of 7000 Arabidopsis genes under drought-, cold- and high-salinity stresses using a full-length cDNA microarray. Plant J. 31:279-292.

Seo, M. and T. Koshiba. 2002. Complex regulation of ABA biosynthesis in plants. Trends Plant Sci. 7:41-48.

Seo, M., A.J.M. Peeters, H. Koiwai, T. Oritani, A. Marion-Poll, J.A.D. Zeevaart, M. Koornneef, Y. Kamiya, and T. Koshiba. 2000. The Arabidopsis aldehyde oxidase 3 (AAO3) gene product catalyzes the final step in abscisic acid biosynthesis in leaves. Proc. Natl. Acad. Sci. USA 97:12908-12913.

Shinozaki, K. and K. Yamaguchi-Shinozaki. 2007. Gene networks involved in drought stress response and tolerance. J. Expt. Bot. 58:221-227.

Subbaiah, C.C., S.C. Huber, M.M. Sachs, and D. Rhoads. 2007. Sucrose synthase expanding protein function. Plant Signal. Behav. 2:28-29.

Torres-Franklin, M.L., D. Contour-Ansel, Y. Zuily-Fodil, and A.-T. Pham-Thi. 2008. Molecular cloning of glutathione reductase cDNAs and analysis of GR gene expression in cowpea and common bean leaves during recovery from moderate drought stress. J. Plant Physiol. 165:514-521.
Troughton, J.H. 1969. Plant water status and carbon dioxide exchange of cotton leaves. Aust. J. Biol. Sci. 22:289-302.

Türkan, I., M. Bor, F. Özdemir, and H. Koca. 2005. Differential responses of lipid peroxidation and antioxidants in the leaves of drought-tolerant $P$. acutifolius Gray and drought-sensitive $P$. vulgaris L. subjected to polyethylene glycol mediated water stress. Plant Sci. 168:223-231.

Umezawa, T., M. Fujita, Y. Fujita, K. Yamaguchi-Shinozaki, and K. Shinozaki. 2006. Engineering drought tolerance in plants: Discovering and tailoring genes to unlock the future. Curr. Opin. Biotechnol. 17:113-122.

Valliyodan, B. and H.T. Nguyen. 2006. Understanding regulatory networks and engineering for enhanced drought tolerance in plants. Curr. Opin. Plant Biol. 9:189-195.

Valluru, R. and W. Van den Ende. 2008. Plant fructans in stress environments: Emerging concepts and future prospects. J. Expt. Bot. 59:2905-2916.

Wang, K. and Y. Jiang. 2007. Antioxidant responses of creeping bentgrass root to waterlogging. Crop Sci. 47:232-238.

Watkins, E. and M.D. Clark. 2009. Genetic improvement of prairie junegrass. U.S. Golf. Assn. Turfgrass Environ. Res. Online 8:1-8.

Wellburn, A.R. 1994. The spectral determination of chlorophylls a and $\mathrm{b}$, as well as total carotenoids, using various solvents with spectrophotometers of different resolution. J. Plant Physiol. 144:307-313.

Yamada, M., H. Morishita, K. Urano, N. Shiozaki, K. YamaguchiShinozaki, K. Shinozaki, and Y. Yoshiba. 2005. Effects of free proline accumulation in petunias under drought stress. J. Expt. Bot. 56:1975-1981.

Zhang, J. and M.B. Kirkham. 1996. Antioxidant responses to drought in sunflower and sorghum seedling. New Phytol. 132:361-373.

Zhang, X. and R.E. Schmidt. 1999. Antioxidant response to hormonecontaining product in kentucky bluegrass subjected to drought. Crop Sci. 39:545-551.

Zulini, L., M. Rubinigg, R. Zorer, and M. Bertamini. 2007. Effects of drought stress on chlorophyll fluorescence and photosynthetic pigments in grapevine leaves (Vitis vinifera cv. 'White Riesling'). Acta Hort. 754:289-294. 